\title{
The Future of Democracy in Chile
}

\author{
Roland Benedikter , Carlos Cruz Infante \& Miguel Zlosilo
}

To cite this article: Roland Benedikter, Carlos Cruz Infante \& Miguel Zlosilo (2021): The Future of Democracy in Chile, Challenge, DOI: 10.1080/05775132.2021.1881294

To link to this article: https://doi.org/10.1080/05775132.2021.1881294

曲 Published online: 22 Feb 2021.

Submit your article to this journal $₫$

Q View related articles $₫$

View Crossmark data $₫$ 


\title{
The Future of Democracy in Chile
}

\author{
Roland Benedikter, Carlos Cruz Infante, and Miguel Zlosilo
}

\begin{abstract}
The situation in Chile after the Constitutional Referendum of October 2020 posits the question: Where is the country headed? Is this the end of a long transition from "adolescent" neoliberal democracy to "mature" welfare democracy-or the start of a new era of uncertainty? Without substantial improvements of the constitutional reform process, its building stones and surrounding conditions, the country is not ready for a systemic transition in reconciliatory and secure manners.
\end{abstract}

\section{Introduction}

On October 18th, 2019, Latin America's economic champion Chile burned-for the first time on such a large scale since the transition to democracy in March 1990. Beginning with a single citizen's dissatisfaction due to the rise of 3.8 percent on the price of the average subway ticket in the capital Santiago, "Chile awoke" to high-level inequality combined with economic uncertainty, as the protesters put it. The result was unrest and upheaval-so violent and on such a large and enduring scale that the country had to shut down its transnational networks for months and cancel international events such as the Asia-Pacific Economic Cooperation (APEC) Trade Forum 2019 and the World Climate Summit 2019 (Zialcita 2019), with devastating consequences on its otherwise excellent international reputation. The sudden explosion of dissatisfaction from apparently substantial parts of the population in the most developed country of the Global South hit the international public rather unexpectedly. What had happened-and what were the reasons?

\section{An Ambiguous Social Situation}

The roots of Chile's complex situation consist largely in the underlying, ambiguous socio-economic ecosystem. While considered the economic champion of Latin America and one of the most developed economies in the world, Chile is ranked only 62nd by

CONTACT Roland Benedikter roland.benedikter@eurac.edu D Drususallee 1, I-39100 Bolzano, Italy.

Roland Benedikter, Dr. Dr. Dr., is Research Professor of Multidisciplinary Political Analysis in residence at the Willy Brandt Center of the University of Wroclaw, Poland; Co-Head of the Center for Advanced Studies of Eureac Research Bozen-Bolzano, Autonomous Province of South Tyrol, Northern Italy; and member of the Future Circle (Zukunftskreis) of the German Federal Ministry of Education and Research (BMBF) for the German Federal Government Berlin. Homepage: http://www.eurac.edu/en/research/center-for-advanced-studies/Pages/default.aspx.

Carlos Cruz Infante, MA, is the former Chief of Strategic Content of the General Secretariat of the Chilean Government and a Content Strategy advisor of the Vice-Minister of Housing of the Chilean Government.

Miguel Zlosilo, MSc, is Chief of Studies of the Secretariat of Communications of the Chilean Government.

(C) 2021 Taylor \& Francis Group, LLC 
the Global Finance Richest Countries in the World 2020 Index (Ventura 2020) due to a comparatively low average of US $\$ 26,317$ per-capita purchasing power (GDP-PPP). According to the German Bertelsmann Foundation's Transformation Index 2020, Chile features "one of the highest levels of inequality in Latin America. Its long-term challenges include major economic and social policy reforms, despite having seen a small boost in economic performance lately" (Bertelsmann Stiftung 2020). While economic transformation is classified by Bertelsmann as "highly advanced" and the average governance index rated "very good," with regard to the political transformation Chile is still in a state of "democracy in consolidation"-with ruptures possible at any moment. The IMF Covid-19 Anti-Corruption Tracker 2020 registered Chile as one of the countries with "no measures against corruption in the Covid-19 crisis" (Transparency International 2020b), and the Corruption Perception Index 2019 listed the nation 26th out of the 180 countries compared, with $13 \%$ of interviewees indicating the necessity to pay bribes for public services and $54 \%$ of Chileans who thought corruption had increased over the past 12 months (Transparency International 2020a), making the geographically "most remote country at the end of the world" (as Chile's aboriginal name suggests) a world rather closed in itself and dominated by a rather small elite where everybody knows everyone, seen as the prerequisite for progress. According to the OECD, of which Chile is a member, despite the nation's good economic performance and comparatively high wealth level $17 \%$ of the population live in relative income poverty, $36 \%$ of poor households spend more than $40 \%$ of their income on housing costs, $13 \%$ say they have no friends or family to turn to in times of need, and $53 \%$ would be at risk of falling into poverty if they had to forgo 3 months of their incomes (Organisation for Economic Cooperation and Development 2020). Combined, these data indicate how tense the socio-economic situation is from the point of view of many families. Although viewed from the outside they seem to have a good standard of living, the subjective perception is that of a permanent threat of existential nature at any moment and despite all efforts made.

Against this backdrop, it becomes understandable how the initial outcry which began with isolated and spontaneous demonstrations against a relatively small price increase of 3.8 percent in public transport could expand to a protest of principle against the very institutional, socio-economic and political foundations of Chile's society. In addition, relatively soon mostly left-leaning advocates of destruction took the protest in their hands, organized it systemically and set the metropolitan subway net on fire. Step by step violence developed everywhere, involving larger parts of the urban population and particularly the middle-class youth. A small flame triggered a large-scale fire which has not stopped since.

\section{Constitutional Referendum}

Obviously, analysts, experts, and the political elites soon realized all this was not merely about the subway. Social unrest had been plaguing Chile's in many ways exemplary, but still young democracy from the start of the post-Pinochet era in 1990, which ironically coincided with the beginning of the neoliberal heydays under the motto "If everybody thinks of himself, everyone is thought of." Expressions of social discomfort from growing sections of the middle class were on the normal agenda of Chilean's everyday life 
over decades. Yet in November 2019, in the face of despair due to the out-of-control mass upheaval and the (partial) loss of face on the international stage, the Chilean government and the larger part of the opposition agreed to realize a long-debated idea: to open the door for a new constitutional process (Senado de la República de Chile 2019). Since discontent had been initiated from the bottom by the citizenry, Chileans would first have to vote on the choice of either initiating a basic reform process of the pillars of the nation, or refraining from it.

Before the referendum, which took place on October 25th, 2020, voter turnout was the main strategic topic. Since the entry into force of voluntary voting in 2011, Chilean elections have aroused doubts about the legitimacy of their outcomes due to low voter participation. Most critics, as for example Claudia Heiss (2016) from the University of Chile, said a participation rate of only around $50 \%$ in the constitutional referendum would be insufficient to consider it a completely democratic and legitimate ballotage to change the fundaments of society and politics of the nation. Although there were hopes for high voter turnout, in the end only $50.9 \%$ of the Chilean citizens voted ${ }^{1}$, choosing, with an overwhelming majority, the "Apruebo" ("I approve") option, that is, the "yes" for the re-writing of the Chilean Constitution at the hands of an elected Constitutional Assembly. Given the disappointing proportion of effective voters, in the eyes of many the process started on the wrong foot, since its outcome could be contested by those who did not participate.

What are the implications and challenges of this new process?

\section{The Political Context}

The first and most important question is about the minimum conditions for a representative and robust new constitution that mirrors the will of the majority of the people. Apart from the poor participation in the vote and its delegitimizing effect, there are structural elements of Chilean politics that may lead objective observers to believe that those minimum terms are still not given. There are four main reasons for this judgment.

\section{High Disapproval Rate of President Sebastián Piñera}

After being elected by the largest number of voters since Chile's return to democracy in 1990 and having trumped in 17 out of the country's 20 poorest municipalities, Mr. Piñera aroused high expectations. Those expectations rapidly deflated at the beginning of the mandate: accusations of nepotism and cronyism (Publimetro 2018), communication mischances (El Líbero 2018), and the perception of improvization by some ministers (Vargas 2018) generated a-in the meantime proverbial-competent executive with an unhappy touch in the eyes of the citizens. Not that this is something new in Chile: without exception, all presidents since the inception of democracy in 1990 have started with high expectations that have fallen sharply afterwards, confirming and re-confirming what analysts call an "adolescent democracy" (Benedikter and Zlosilo 2017), that is, an over-ambitious and over-enthusiastic public that must necessarily be disappointed by reality every time history opens the door to exaggerated hopes.

After a while, Mr. Piñera's government despite notable successes praised by the international community seemed to have disappointed Chileans again (as his predecessors 
did with great regularity), this time regarding the economic balance sheet. In his first term (2010-2014), the country's economy thrived, and unemployment decreased to unprecedented minimums. After one of the worst earthquakes in world history on February 27th, 2010, since March of that same year the president had successfully rebuilt the country and in August rescued 33 miners with all the odds against him. Confident of his previous results, Mr. Piñera's central campaign for his second term (since 2018) promised there would be "better times" (Tiempos mejores). Yet according to surveys among the population in February 2019, one year into his second term fewer than expected seemed to (psychologically and factually) perceive them (Criteria Research 2019).

From there, the situation went into a tailspin. According to Cadem Research, a Chilean polling company, President Piñera started his second term with a 58\% approval rate in March 2018. This plunged to 37\% after one year, and never rose beyond $40 \%$ again. At the end of 2020 his approval rates oscillated between 15\% and $25 \%$ not least due to the bombardment of criticism from political and civil society sectors during and after the upheaval since October 2019 (Strategic Comments 2020). Another contributing factor has been the Covid-19 crisis which hit Chile hard with more than 550,000 infections and more than 15,000 deaths (Worldometers 2020). The culprit of the devastating effect of the China-stemming virus was soon found in the president, as usual in "adolescent democracies" still to some extent used to putting all the blame on the "strong man above"-which was not completely fair since Piñera, learning from his first term, tried really hard to not be the lonely one at the top but one among many.

Mr. Piñera's position was also weakened due to the internal crisis of Chile Vamos, his center-right coalition that sponsored the president's re-nomination and campaign. As a manifestation of discord, in July 2020, the congress members of Chile Vamos supported a bill to allow the people to withdraw $10 \%$ of their retirement savings to palliate the Covid-19 pandemic effects (Cooperativa.cl 2020). This was a frontal attack against Piñera's will (Montes 2020), as he had tried to keep the finances of the pension system sustainable.

\section{Legitimacy Crisis of the Political System}

According to the renowned Santiago-based conservative think-tank Centro de Estudios Públicos, in December 2019 less than two-thirds of Chileans were of the opinion that democracy is preferable over any other form of government (CEP 2020). Political parties in 2020 had a mediocre approval rate of $2 \%$. Government and National Congress' approval only reach $5 \%$ and $3 \%$, respectively. How, then, would it be possible to elaborate on a new constitutional chapter with such meager figures of the main actors and responsible players involved? Although Chileans voted to elect a Constitutional Assembly from scratch, the "independent" candidates for this organism will be backed by the parties in one way or another. Furthermore, most aspirants for the Constitutional Assembly are retired politicians who already have greater awareness and system integration than any ordinary citizen and know well how to campaign successfully-within the given system. 


\section{Coalitions in Crisis: Lack of Leadership and Warlordism}

Regardless of their political color, all Chilean parties today show internal cracks. Historical leaders have resigned from their conglomerates due to irreconcilable differences with the respective directives or voterships, so political re-alignment and reconciliation have become difficult, if not impossible. At the same time, that begets new warlords trying to conquer the vacuums of power within and among parties, and erode partisan life. In Chile, "warlordism" has become a new political etiquette, denoting an unforgiving "Us against them" rhetoric now en vogue among the many disappointed on all sides.

The clearest and most recent example of the fragmentation and hybridization of Chile's political party landscape was the emergence of Frente Amplio (Broad Front). This is a coalition of social movements and parties with influential individual leaders but no alignment among the bases. More serious is that warlordism is an autopoietic phenomenon, as Humberto Maturana would put it. This became apparent when the government's opposition could not even concretize a joint strategy in the "Apruebo" campaign context, to which all of them agreed in principle. The Communist Party (Partido Comunista de Chile) used this to profile itself as a potential new unifying platform for all opposed to the government. It certainly is to blame for a new, more aggressive tone in Chilean politics which tries to foster polarization and wants to give birth to a new "leftist populism," not least by recurring to the ideas of Italian philosopher and politician Antonio Gramsci (1891-1937) (Benedikter 2017). Its members still celebrate Cuba's and Venezuela's dictatorships. Their ambiguity in not condemning human rights violations by Latin America's radical left while constantly blaming the West for everything that goes wrong has generated irreparable wounds with the old Concertacion, the moderate leftist bloc that led to the transition to democracy after Augusto Pinochet's regime, and particularly with one of its party members, the centrist Christian Democratic party (Partido Demócrata Cristiano).

\section{Constitutional Assembly Elections and Territorial Elections Coincide in 2021}

There are 12 political elections taking place in Chile during 2021. The Constitutional Assembly members polls will coincide with governors and majors' elections. This means that the grand constitutional re-definition and the territorial micro- and meso-battles of the political parties will occur simultaneously. The former will probably be distorted by the latter, putting politicians to the test of territorial sub-interests and thus the countrywide constitutional project at grave risk.

\section{Conclusion: The Post-Referendum Scenario. Five Main Challenge Clusters}

As expected, the referendum event brought both risks and opportunities for the postreferendum era. Among the risks is systemic uncertainty that will be a problem throughout the entire constitutional process, which is foreseen to end in 2022. The civil violence since October 2019 and the subsequent pandemic have already caused the Chilean economy to stagnate. Two more years of stepping on eggs because of the 
insecure constitutional process could frighten foreign investments, supranational organisms, and commercial partners, and paralyze risk assessment institutions.

Aside from unpredictability, the process raises the following five main challenge clusters:

Firstly, since as mentioned participation in the referendum was by far lower than expected (50.9\%), efforts to make the new constitution legitimate must double. The awareness that now is a once-in-a-lifetime chance to improve the fundamental law and values structure of Chile toward a more participatory one better oriented to public welfare, moving beyond neoliberal patterns and replacing some of Pinochet's groundings, may help to mobilize the youth. If it comes to fruition, this would be the first time in Chilean history that the constitution will emanate from citizen participation and not simply "from above."

Secondly, between 30\% and 50\% of the "Apruebo" ("I approve") votes of October 2020 came from the center-right, that is, from voters who are unwilling to elect center-leftist candidates for the Constitutional Assembly but could nevertheless vote for persons independent of their political ideology. That factually impedes any pro-reform party from clearly predicting and designing a political and communication strategy to set their main ideological ideas in advance. Strategies have to be adapted according to the unpredictable mixture of voters clinging to certain goals and interests in the constitutional process.

Thirdly, as seen above, the leftist opposition has been unable to conceal its overdiverse spectrum of political tendencies and to converge it to a shared position with regard to the constitutional process. The same will probably happen to the pro-government conservative parties. At least half of them backed the "Rechazo" ("I reject") option to halt the constitutional renewal process, also due to the fact that some of its bestknown politicians participated in one way or another in Pinochet's regime.

In such a context, agreements about the constitution's contents and candidates for the assembly will remain mostly unobtainable for both sides, which is a problem for the country as a whole, not just for any particular party or ideology.

Fourth, the constitutional assembly is supposed to be partially filled with independent representatives, which in reality is exceptionally difficult, as outlined previously. On that particular aspect, Patricio Navia (2020), a Chilean Professor at New York University, rightly stated that

There will likely be disappointment among many voters when they see that the composition of the constitutional assembly does not reflect the idealized conception of a representative group of Chileans from all walks of life meeting to deliberate on the framework of a more just and equitable society.

Fifth and lastly, the most challenging problem is the public expectation about the new constitution itself. Since former president Michelle Bachelet (2006-2010 and 2014-2018) repeatedly promised to conduct a constitutional innovation process, a pledge that allowed her win in the ballots and achieve her second term (2014-2018), Chileans share the misconception that including social rights into the Magna Carta will fix all the country's flaws overnight. In a poll of La Tercera and Ipsos of December 2019 (Rivas 2019), 50\% thought that a new constitution will improve the retirement pensions; $47 \%$ said it would increase the minimum wage. A little under one third stated that it would reduce the public healthcare waiting lists. 
María Jaraquemada (2020), advocacy director of the Chilean leftist NGO think tank Espacio Público, which actively supported the "Apruebo," commented that

Misinformation in the run-up to the referendum has complicated the process, giving ammunition to defenders of the status quo. There are campaigns that claim that a new constitution would change peoples' lives completely. Others argue that nothing would change and no reforms would happen. And while the idea is not widespread, some extreme leftist movements are even claiming that if the approve vote wins by $80 \%$ or more, this will be a referendum on President Sebastián Piñera's government, and he might have to leave office. This is simply not true, but speaks to the polarization in Chilean politics.

\section{Outlook}

The future of Chile's democracy is uncertain, as it has been during the whole transition process from dictatorship (1973-1990) to "adolescent neoliberal democracy." The doubts whether the next phase, starting in 2022, could be the step toward a "mature welfare democracy" relate to political system's inability to include the growing demand for participation by independent candidates and the will of the political leaders for renewal. As Chile is a country of "family politics" where many have created their personal niches in which they live well, established politicians will have to decide whether they want to defend their traditional ecosystem or initiate a real transformation process that includes opening up their own share of the system.

Summing up, there are five main challenges presented by the upcoming Chilean constitutional process: the public legitimacy of the process given the low participation rates; the inability of both leftist and rightist parties to plan content and election strategies for the next stage of the process, which will be the election of the assembly members; the lack of consensus reaching common values and principles for the new constitution; the unavoidably political character of potential constitutional assembly members, who have claimed to be apolitical; and the over-expectations of Chileans regarding the new constitution.

President Piñera now needs a breeze of calm, and the protesters in the streets should let him work. He would do well to focus on following the procedures correctly and promoting dialogue at every level, including with friendly and opposed political parties, civil society and the envisaged "independent" assembly members to be elected in April 2021. Piñera knows well that if he acts otherwise he could arouse further outrage on the part of his critics, damaging not only his legacy but the entire process. This is why Chileans need a pinch of positivity about their government.

Since uncertainty about the outcome will continue at least until 2022, when a new referendum will ratify or dismiss a newborn constitution, the government, from its side, has to do everthing possible to keep public order and to ensure continuity. So far the social movements "from below" are still active spectators, and violence may return repeatedly throughout the process. On the other side, the radical left, led by a degenerated Communist Party, must condemn violence much more decisively and reject it as a political tool if they expect to have their fingerprint in improving the Chilean Magna Carta.

Finally, and most important, public expectations need to be a dash more moderate. The campaign to remove Pinochet from power in the 1980s went: "Chile, joy is coming" 
(Chile, la alegría ya viene). Most Chileans would say that regarding their own lifes, this has not happened yet. Later on, Mr. Piñera successfully promised "better times" (Tiempos mejores), but approval rates and the economy's perception show that most Chileans perceive this did not happen yet either. As a result, some exaggerate the potential of a new constitution to change everyday life, following Mrs. Bachelet's promises that it will fix "everything" in Chile for good. Most certainly, this will not happen, and not so fast as envisioned. To avoid another popular disappointment, not just the government, but the whole political elite must make sure to communicate the real possibilities of the constitutional process, and identify issues that need further discussions by actively including the citizenry. If this does not happen, Chile is not yet ready for the envisaged grand transition.

\section{Note}

1. In comparison, according to the Electoral Service of Chile (www.servel.cl) voter turnout in the second round of Chile's national presidential and parliamentary elections of 2017 reached just $49.02 \%$.

\section{Further Reading}

Benedikter, R. 2017. "Gramsci is Not the Answer. Does the Left Need a New Populism?" GlobalE. A Global Studies Journal 20 (25)

Benedikter, R., and M. Zlosilo. 2017. "Chile: An Adolescent Democracy Heads to the Polls." Accessed November 1, 2020. https://www.coha.org/chile-an-adolescent-democracy-heads-tothe-polls/.

Bertelsmann Stiftung. 2020. “BTI Transformation Index.” Accessed October 31, 2020. https:// www.bti-project.org/en/reports/country-dashboard-CHL.html.

CEP. 2020. "Estudio Nacional de Opinión Pública N ${ }^{\circ}$ 84." Accessed October 30, 2020. https://www.cepchile.cl/cep/site/docs/20200116/20200116081636/encuestacep_diciembre2019. pdf.

Cooperativa.cl. 2020. "Con votos de Chile Vamos: Senado aprobó el retiro del 10\% de los fondos previsionales.” Accessed October 31, 2020. https://www.cooperativa.cl/noticias/economia/sistema-previsional/afp/con-votos-de-chile-vamos-senado-aprobo-el-retiro-del-10-de-los-fondos/ 2020-07-22/203348.html.

Criteria Research. 2019. “Agenda Ciudadana Criteria Febrero 2019.” Accessed October 28, 2020. https://www.criteria.cl/wp-content/uploads/2019/05/ACC-Febrero-2019.pdf.

El Líbero. 2018. "Balance oficialista del primer semestre de Piñera. Lo bueno: migración y economía; lo débil, la comunicación con el sector.” Accessed February 14, 2021. https://ellibero.cl/ actualidad/balance-oficialista-del-primer-semestre-de-pinera-lo-bueno-migracion-y-economialo-debil-la-comunicacion-con-el-sector/.

Heiss, C. 2016. “Abstención electoral y participación política." Accessed October 31, 2020. https://www.uchile.cl/noticias/127887/abstencion-electoral-y-participacion-politica.

Jaraquemada, M. 2020. “Chile Can't Wait Longer for a New Constitution." Accessed October 30, 2020. https://www.americasquarterly.org/article/chile-cant-wait-longer-for-a-newconstitution/.

Montes, R. 2020. "La derecha oficialista se rebela contra Sebastián Piñera en Chile." Accessed October 31, 2020. https://elpais.com/internacional/2020-07-10/la-derecha-oficialista-se-rebelacontra-sebastian-pinera-en-chile.html.

Navia, P. 2020. “The Politics of Chile's New Constitution.” Accessed October 31, 2020. https:// www.americasquarterly.org/article/the-politics-of-chiles-new-constitution/\#.X5daRSODoTE. linkedin. 
Organisation for Economic Cooperation and Development. 2020. "OECD Better Life Initiative: How's life in Chile?" Accessed November 1, 2020. https://www.oecd.org/chile/Better-LifeInitiative-country-note-Chile.pdf.

Publimetro. 2018. "Nepotismo: sigue aumentando la lista de familiares en el gobierno." Accessed October 30, 2020. https://www.publimetro.cl/cl/noticias/2018/05/08/nepotismo-gobierno-pinera. html.

Rivas, S. 2019. “¿Qué piensan los chilenos sobre una nueva Constitución? 60\% espera que el tema se resuelva durante 2020." Accessed October 31, 2020. https://www.latercera.com/la-tercera-pm/noticia/que-piensan-los-chilenos-sobre-una-nueva-constitucion-60-espera-que-el-temase-resuelva-durante-2020/957554/.

Senado de la República de Chile. 2019. "Logran histórico acuerdo para Nueva Constitución: participación ciudadana será clave." Accessed October 30, 2020. https://www.senado.cl/logran-historico-acuerdo-para-nueva-constitucion-participacion/senado/2019-11-14/134609.html.

Strategic Comments. 2020. "Political Unrest in Chile." Strategic Comments 26 (3):i-iii.

Transparency International. 2020a. "Country Data Chile.” Accessed November 1, 2020. https:// www.transparency.org/en/countries/chile.

Transparency International. 2020b. "IMF COVID-19 Anti-Corruption Tracker." Accessed October 31, 2020. transparency.org/en/imf-tracker.

Vargas, F. 2018. “¿Errores no forzados del Gobierno?: Expertos advierten que ministros de Salud y Educación pueden quedar "condicional” Fuente." Accessed October 31, 2020. https://www. emol.com/noticias/Nacional/2018/04/18/902909/Errores-no-forzados-del-Gobierno-Expertosadvierten-que-ministros-de-Salud-y-Educacion-pueden-quedar-condicional.html.

Ventura, L. 2020. "Global Finance." Accessed November 6, 2020. https://www.gfmag.com/globaldata/economic-data/richest-countries-in-the-world.

Worldometers. 2020. "Worldometers: Coronavirus in Chile." Accessed November 1, 2020. https:// www.worldometers.info/coronavirus/country/chile/.

Zialcita, P. 2019. "NPR.” Accessed November 6, 2020. https://www.npr.org/2019/10/31/ 774862059/as-protests-persist-chiles-president-cancels-two-major-international-summits?t= 1604641347982 . 